\title{
Relationship between innovation-led HR policy, strategy and firm performance: a serial mediation investigation
}

Article

Accepted Version

Do, H., Budhwar, P. S. and Patel, C. (2018) Relationship between innovation-led HR policy, strategy and firm performance: a serial mediation investigation. Human Resource Management, 57 (7). pp. 1271-1284. ISSN 1099050X doi: https://doi.org/10.1002/hrm.21903 Available at https://centaur.reading.ac.uk/74975/

It is advisable to refer to the publisher's version if you intend to cite from the work. See Guidance on citing.

To link to this article DOI: http://dx.doi.org/10.1002/hrm.21903

Publisher: Wiley

All outputs in CentAUR are protected by Intellectual Property Rights law, including copyright law. Copyright and IPR is retained by the creators or other copyright holders. Terms and conditions for use of this material are defined in the End User Agreement.

www.reading.ac.uk/centaur 
Central Archive at the University of Reading

Reading's research outputs online 


\title{
Relationship Between Innovation-led HR Policy, Strategy and Firm Performance: A Serial Mediation Investigation
}

\begin{abstract}
This research examines the relationship between innovation-led strategy and innovation-led HR policy (hereafter, management initiatives), and innovation performance. Our research model is theorised and tested in the Vietnamese context, based on servant leadership theory and componential theory of creativity. We draw upon constructs of management initiatives, servant leadership, employee creativity, and firm innovation to hypothesize serial mediation mechanisms linking management initiatives to firm performance. Using a multilevel sample of 56 service firms, we conduct multilevel path analyses. We find that (1) individual-level servant leadership mediates the top-down relationship between management initiatives and employee creativity; (2) employee creativity mediates the bottom-up relationship between individual-level servant leadership and firmlevel innovation; and (3) firm-level innovation mediates the bottom-up relationship between employee creativity and firm-level market performance. We conclude by discussing both theoretical and practical implications.
\end{abstract}

\section{Keywords:}

Innovation Strategy Execution, Innovation-led HR Policy, Management Initiatives, Servant Leadership Theory, Componential Theory of Creativity, Employee Creativity, Innovation. 


\section{INTRODUCTION}

Innovation has been construed as "a cure-all medicine for all kinds of issues that firms face - including ensuring profitability, revenue growth, loyal customer base, and increased efficiency" (Adner, 2012, p. 159). Accordingly, management scholars advocate that innovation has been an important source of competitive advantage (Prajogo \& Ahmed, 2006; Tushman, Anderson, \& O'Reilly, 1997). This is because innovations in products or services are believed to be necessary if an organization must succeed in today's turbulent market (Adner, 2012). Drawing upon this logic, we argue that innovation is a must for organizations to advance their manufacturing and service delivery to achieve superior performance in order to deal with turbulence in the external environment (Jiménez-Jiménez \& Sanz-Valle, 2011). However, it is noteworthy that success in innovation is influenced by different factors such as leadership style, organizational learning, organizational structure, human capital, work environment and the like (Gumusluoglu \& Ilsev, 2009; Jung, Chow, \& Wu, 2003; Lorenz \& Valeyre, 2005). Of these, people are considered as one of the central ingredients in contributing to firm success (Prajogo \& Ahmed, 2006). The reason behind this philosophy is that as innovation is 'essentially about converting ideas into something profitable, encouragement to supply ideas needs to be substantial in order to channel the creative ability of the employees to convert ideas into innovations' (Prajogo \& Ahmed, 2006, p. 502). These authors further suggest that firms should foster innovation by building and retaining a favourable environement for creativity and idea production (Prajogo \& Ahmed, 2006).

As such, we argue that innovation-led strategy and innovation-led HR policy are central to the practices of managing the human factors of innovation (see Prajogo \& Ahmed, 2006). Firms need innovation strategies to achieve successful innovation outcomes. For example, Nortel Networks' failure to recover after the 2000 crisis was ascribed to the 
company's lack of direction and innovation (Cooper \& Edgett, 2010). Also, adoption of innovation-focused HR policy is an important element of organizational design. For example, such policy facilitates a culture that is supportive of risk taking and innovation (France, Leahy, \& Parsons, 2009). Thus, innovation-focused HR policy is essential to the achievement of organizational innovation strategies. It is for this reason that the focus of innovation-led strategy and innovation-led HR policy is on the delivery of added value via 'soft' management practices that are strategic in connecting these practices to the goals of the firm and its external context, thereby contributing to firm outcomes (Golding, 2010). Despite the recognized role, our literature review indicates that the two constructs have been understudied, with one notable exception- the work by Oke, Walumbwa, and Myers (2012) who examined the interactions of innovation strategies and innovation-led HR policy implementation on firm innovation and revenue growth. Not surprisingly, this gap is further exacerbated in the case of a non-Western context like Vietnam.

In light of the above, an attempt is made in this research to extend this stream of research and also fill this gap in a non-Western context. We therefore develop a cross level model of innovation strategy and innovation-led HR policy execution and performancerelated outcomes (see Figure 1) to sharpen the influence of such practices on organisational performance. Specifically, this study aims to test both top-down and bottom-up relationships between (1) management initiatives and employee creativity mediated by individual-level servant leadership (top-down relationship); (2) individual-level servant leadership and firmlevel innovation mediated by employee creativity (bottom-up relationship); and (3) employee creativity and firm-level market performance mediated by firm-level innovation (bottom-up relationship). This study is therefore among the first to 'address both top-down and bottom-up relationships and thus to bridge micro and macro domains - arguably one of the biggest future 
challenges in management research' (Nohe, Michaelis, Menges, Zhang \& Sonntag, 2013, p.379). Accordingly, the study contributes to the existing knowledge in this aspect along with a non-western context evidence- Vietnam.

Vietnam provides a particularly meaningful context for this research. Like other emerging economies, Vietnam has become more open to the outside world via foreign trade and investment (Zhu \& Verstraeten, 2013). Due to the pressure of regional economic cooperation and global economic integration, Vietnamese firms have rapidly transformed people management systems from personnel management to HRM practices to create their competiveness (see also Zhu \& Verstraeten, 2013). To do so, Vietnamese organizations have embarked on an innovation-based model, which entails the pursuit of a modern management path (Murphy, 2002). It is expected that, if properly implemented, management initiative practices are likely to make use of the knowledge, skills, abilities and willingness of employees to activate their creativity (Fu, Flood, Bosak, Morris, \& O'Regan, 2015). Also of note is that organizations are increasingly becoming aware that people management is central to modern administration management practices (see Vo \& Hannif, 2013; Cabrera \& Cabrera, 2005).

Also of interest is that the literature review suggests that the majority of HPWS research has obtained data from manufacturing industries, ignoring the very important service counterpart. Hence, there have been many calls for undertaking research in the latter (Harley, Allen, \& Sargent, 2007; Liao, Toya, Lepak, \& Hong, 2009). In response, recent scholars have paid attention to the service industry (Aryee, Walumbwa, Seidu, \& Otaye, 2012; Ang, Bartram, McNeil, Leggat, \& Stanton 2013; Michaelis, Wagner \& Schweizer, 2015; Zhang et al., 2013). For example, using a sample of junior enterprises in Germany, Michaelis et al. (2015) demonstrate that knowledge exchange and combination of knowledge mediates the 
relationship between HRM and workforce productivity. In this regard, Vo (2009) highlights that human resources in Vietnam are increasingly seen as having strategic and financial implications, and competitive pressures will result in the development of management systems toward Western-style HR policies and practices. Nonetheless, Vo (2009) notes that the extent to which Vietnamese organisations implement new HR practices changes substantially and is greatly contingent on the collective views of each organisation's board of directors and top managers about the significance of HRM function regarding the firm's goals and vision. This in turn decides the firm's support and investment to the development of this function.

Vietnamese firms are therefore interested in borrowing and implementing innovative HR practices to foster their performance at both individual and firm level (see also Zhang \& Morris, 2014). It is for this reason that organisations cannot wait for empirical evidence to accumulate before deciding which HR practices to execute (Ramdani, Mellahi, Guermat, \& Kechad, 2014), while they need to adopt "best HR practices"e as a win-win solution to achieve competitive advantage and enhanced firm performance. Second, multinational companies operating in Vietnam usually implement Western HR practices, and their actual execution has demonstrated the efficacy of such practices. Therefore, Vietnamese firms that wish to pursue innovative HR practices often learn and translate "best practices" into their actual implementation. Finally, Vietnamese organisations now prefer to promote young leaders, who are willing to adopt modern management styles, and thus adopt and implement HRM practices from Western countries (see also Vo \& Hannif, 2013).

Taken together, Vietnamese organisations have embraced a modernization path, which involves the implementation of global "high performance" practices (Murphy, 2002; Ramdani et al., 2014). However, it is noteworthy that despite the widespread adoption of Western HR 
practices, Vietnamese organisations tend to incorporate such practices with Vietnam-specific HR practices so that their HR practices can work well in the workplace. As such, Vietnam provides a particularly meaningful context for this research.

Our study therefore contributes to the relevant literature in several ways. First, the study contributes to the literature by highlighting the importance of innovation components within higher organizational strategy to help an organization to achieve its set goal. For example, if the outcome goal of the organization is innovation, having management practices bearing components that facilitate its outcome is of utmost significance. This study is therefore among a few to investigate the efficacy of innovation-led strategy and innovationled HR policy as organizational strategy on both individual and firm performance outcomes. Another important contribution of the study is that it examines the efficacy of HR strategy on firm performance channelized by some of the important individual outcomes such as servant leadership and employee creativity. Of these, servant leadership is construed as the most important construct because leaders or immediate supervisors are the main carriers or implementing agents of such strategy. Finally, this study contributes to the management literature by linking HR practices, firm strategies, innovation-related issues, and insights from servant leadership and creativity theories to test the link between management initiatives and innovation performance. By doing so, we answer the need to advance HR theories to account for the management practices-performance relationship (see Beugelsdijk, 2008; Colbert, 2004; Guest 1997), and bridge the theoretical perspectives with empirical evidence. Figure 1 summarizes our conceptual model. These contributions of the study along with its practical implications are further elaborated later in the paper.

Insert Figure 1 about here 
The reminder of the paper is structured as follows. First, we provide the theoretical background connecting management initiatives with servant leadership, employee creativity, innovation, and then market performance. This theoretical foundation subsequently constitutes the hypotheses that are tested by using a multi-rater sample of Vietnamese service organizations. The paper then outlines the methods adopted for this analysis. Next, the results are presented, which is followed by discussion. Lastly, the implications, future research directions and conclusions are presented.

\section{THEORETICAL BACKGROUND AND HYPOTHESES}

Innovation-led strategy and innovation-led HR policy have been viewed as two critical management initiatives (Oke et al., 2012) and as salient antecedents of organizational innovation performance. Despite being recognized as antecedents of different indicators of firm performance (see Oke et al., 2012; Beugelsdijk, 2008), this study is among the first to explore the interaction of innovation strategy execution and innovation-led HR policy on innovation-related outcomes through the indirect effects of individual-level outcomes (e.g., perceived servant leadership and employee creativity). By relating the HR and other-related literatures to the insights from servant leadership theory and componential theory of creativity, we develop the hypotheses on the linkages between such management initiatives, and individual and organizational innovation-related outcomes.

\section{Innovation-led Strategy and Innovation-led HR Policy towards Management Initiatives}

Innovation is a must for many firms to strive in the current market turbulence (Prajogo \& Ahmed, 2006), and thus innovation strategies are becoming increasingly important for firms to improve their innovation performance. In this regard, innovation-led strategy is conceptualized as 'the extent to which innovation is a priority in a firm as reflected by the 
specific actions or plans taken by the firm to promote innovation' (Oke et al., 2012, p. 274). Scholars advocate that the implementation of an innovation strategy can serve as a response strategy by management to accomplish innovative performance targets, product development and/or new service introductions (Oke et al., 2012). As such, innovation strategies are an essential instrument for firms to achieve the development of innovation. However, we note that innovation-led strategy is only a necessary condition but not sufficient to ensure firms' success in innovation. As such, it is argued that this management practice needs to be interacted or complemented with other related management practices such as innovation-led HR policy to enable firms to achieve their goals.

Underpinned by the resource-based perspective (Barney, 1991), Beugelsdijk (2008) holds that HR practices that are strategically targeted toward shaping employee creativity facilitate organizations to produce innovativeness, and thus create a source of competitive advantage. This is because HR practices that represent the firm's strategic goals and investment could be a potential enabler to constitute the pool of unique workforce in order to yield competitive advantage to the firm (Barney, 1991; Shin \& Konrad, 2017). Following this logic, we argue that traditional HR practices are not in a position to enable a firm to achieve this goal. Instead of designing and implementing such HR practices, the firm needs to execute more innovative HR practices, which are led by innovation-led HR policy. As such, innovation-led HR policy is described as 'the extent to which a firm adopts people-focused policies including recruitment and selection, and reward systems that foster the development of innovation (see Beugelsdijk, 2008; Oke et al., 2012). There is evidence that employee creativity and innovation performance can be enhanced if firms implement innovative HR practices effectively (Beugelsdijk, 2008; Jiang, Wang, \& Zhao, 2012; Messersmith \& Guthrie, 2010). For example, task autonomy and employee empowerment can facilitate creativity and 
innovation, and extensive training is related to higher innovative performance (Beugelsdijk, 2008). More evidently, the execution of HR practices influences sales growth and firm innovation (Messersmith \& Guthrie, 2010). These empirical demonstrations lay a solid foundation that innovation-led HR policy adopted in this study is likely to be one of the key factors to the development of organisational innovation. However, like innovation-led strategy, innovation-led HR policy is only a necessary condition but not enough to contribute to firm success. We therefore argue that the two constructs must be interactively combined in order to complement each other, thereby becoming a neccessary and sufficient condition to enable firms to achieve higher innovation. When combined, they are are likely to mutually support each other to foster and shape a culture of firm innovation. Following this logic, this study starts from the complementarity view that different practices can complement with one another to yield better outcomes (see Oke et al., 2012). We therefore incorporate innovationled strategy and innovation-led HR policy into one combined construct that predicts both individual- and firm-level outcomes. In support, Oke et al. (2012) point out that innovationled HR policy is a central component of firm design, thereby channeling firm innovation strategies. Oke et al. (2012) further add that the efficacy of innovation strategies might also be contingent on the firm's implementation of the HR policy. In support, scholars argue that HR practices need to be aligned with other aspects of the firm to make sense of their execution (Beugelsdijk, 2008). Similarly, Laursen and Foss (2003); Katou and Budhwar (2006); Lau and Ngo (2004); Selvarajan et al. (2007); and Shipton et al. (2006) explore the positive links between certain HRM practices and innovation.

Youndt, Snell, Dean, and Lepak (1996) further support that 'the impact of HR practices on firm performance may be further enhanced when practices are matched with the competitive requirements inherent in a firm's strategic posture' (1996, p. 837). Hence, Oke et 
al. (2012) conclude that the two management initiatives can complement with each other because coherently bundled practices are mutually supportive (see also Holcomb \& Hitt, 2007). Evidently, Oke et al. (2012) provide empirical support for this underlying assumption. We therefore argue that innovation-led strategy emphasizing the firm's goals should be aligned with innovation-led HR policy functioning as management practices to accomplish the set goals. In order to explore the efficacy of management initiatives on firm performance, we conduct a series of mediation tests both at the individual- and firm-level to provide a more comprehensive picture of such a relationship. We now discuss the mediating role of servant leadership, employee creativity and firm innovation in the management initiativesperformance relationship in turn.

\section{Mediating Role of Servant Leadership}

Literature demonstrates that there is a close link between leadership and employee creativity (Reiter-Palmon \& Illies, 2004; Rosing, Frese, \& Bausch, 2011; Tierney, Farmer, \& Graen, 1999; Wang \& Cheng, 2010). For example, Reiter-Palmon and Illies (2004) argue that creative outcomes will unlikely be realized without a certain degree of support from organizational leaders. This is also empirically supported by recent research on the link between leadership styles and creativity (Gong, Huang, \& Farh, 2009; Gumusluoglu \& Ilsev, 2009; Haq et al., 2010; Jung et al., 2003; Shin \& Zhou, 2003; Wang \& Rode, 2010). As with any other leadership styles, servant leadership has its unique values and is relevant to the leadership scholarship (Russell, 2001). The literature suggests that servant leaders' behaviors (e.g., provide guidance to develop followers), intentions (e.g., willingness to sacrifice for others), and values (e.g., employing ethically justifiable means) generate followers' respect and loyalty (Liden et al., 2008; Neubert et al., 2008; Sendjaya et al., 2008; van Dierendonck, 2011; Walumbwa, Hartnell, \& Oke, 2010). Servant leadership focuses more on the perceived 
quality of followers' development in multiple dimensions of self (e.g., emotional, spiritual). For example, servant leaders value human equality and seek to improve the personal development and professional contributions of all organizational members. Hence, Yoshida et al. (2014) advocate that the internal values of servant leaders generate functional, distinguishable leadership attributes, thereby creating a powerful and personal motivation for followers to embark upon creative endeavors.

To illustrate this further using relational identification theory, we argue that followers identify themselves in terms of their relationship with servant leaders because in followers' eyes, these leaders are attractive (Cooper \& Thatcher, 2010). This results in meeting of followers' social-psychological needs due to leaders' genuine interest over followers' needs and perspectives. Such relational identification, in turn, fosters empathy, liking and cooperation to achieve a common goal, which is also in opportune for followers' interest. Followers who see themselves as a reflection of the leader-follower relationship will be more willing to experiment with new ideas because there is a strong sense of psychological safety in such relationship. Research suggests that a psychologically safe team is better placed to succeed in their creative endeavors (Baer \& Frese, 2003). Given its primacy on the followers' need and welfare, servant leadership would encourage a positive social climate in which followers feel accepted and respected. Such constructive relationship provides a perfect social environment/context for creativity to foster- it is this link within the componential theory of creativity. Whereas the innovation-led strategy and HR policy provide the perfect social environment (according to componential theory of creativity); servant leadership provides for a positive leader- follower relationship that serves followers' task related needs (high domain expertise and high skills in creative thinking) and social-psychological needs (psychological safety) in an environment high in supports for creativity. 
On the basis of the above theoretical and empirical demonstrations, we rely on servant leadership theory to argue that innovation-based organizations that effectively invest in highly motivated and qualified employees via management initiative practices are more likely to achieve higher innovation performance and business success than those do not. This is because efficient systems and processes are only successful if the people who make them work are efficient and competent (Shekari \& Nikooparvar, 2012). We therefore argue that leaders who can inspire and enable their subordinates through investing in them and empowering them to do their best (Shekari \& Nikooparvar, 2012) are those who play an important role in contributing to the overall success of the organization. Relatedly, servant leaders represent the firm as creating a cultivating and supportive work environment for individuals to innovate and perform (Zhang et al., 2012). As such, we postulate that when leaders do their jobs well as servant leaders, they will translate their inspiration and motivation into subordinates. Employees accordingly become more intrinsically motivated to work, innovate and contribute, thereby shaping employee innovative behaviors. This is coupled with the central principle of servant leadership theory that the purpose of servant leaders is to enable and encourage their followers to develop for their own good, and see the development of subordinates as an end, in and of itself, not merely a tool to accomplish the leader's or organization's targets (Shekari \& Nikooparvar, 2012).

Also of interest is that management scholars advocate that management practices can be associated with organisational performance from two facets: how to motivate workers to create novel ideas, and how to enable them to perform such ideas (Jiang et al., 2012). Furthermore, Searle and Ball assert that the issue for organizations that value innovation is 'how to select, develop and motivate individuals capable of formulating ideas in the first place, and also to create the supportive environment in which groups can productively and 
swiftly implement them' (2003, p. 51). This view is particularly well aligned with some components of servant leadership theory that the primary focus of servant leaders is on their responsibility for building a safe and supportive work environment that facilitates creativity and innovation, and stimulates intrinsic motivation (Wong \& Davey, 2007). This means that when employees perceive that they are supported and provided the opportunity to perform their job duties in their own way in such a positive work environment, they are more willing to take risks and always innovate in their work in order to return their organizational support and investment. This is because employees' creative behaviors stemmed from servant leaders' radical approach that motivates them through a positive work environment are expected to 'make individuals work more, produce higher quality work and feel more comfortable engaging in behaviors that put them at risk, such as suggesting creative ideas that violate expected norms (Madjar \& Ortiz-Walters, 2009, p. 130).

Although some aspects of innovation strategies have been found to positively affect the innovation performance of firms (Crespell \& Hansen, 2008), the effectiveness of innovation strategies largely depends on the HR policy that a firm adopts. This is because HR issues are central to the strategy of firms (Barney, 1991; Lado \& Wilson, 1994; Laursen \& Foss, 2003). For instance, adopting innovation-focused HR policy is likely to lead to highly skilled employees who have the required expertise to solve innovative and difficult problems, and highly motivated individuals who are able to go the extra mile to search for new ideas (Amabile, 1998; 1996; Seijts \& Lathman, 2005). In addition, HR policy that includes rewards and recognition systems that encourage innovation are likely to facilitate an innovative organizational culture. Such a culture tends to be supportive of a firm's innovation strategy because it creates an environment that rewards success, promotes risk taking, and provides freedom to experiment (Burns \& Stalker, 1961; Damanpour, 1991). As such, the execution of 
innovation strategies is likely to be complemented by the adoption of innovation-focused HR policy. Based on such theoretical developments, we position servant leadership as an important mediator that channelizes the relationship between management initiatives and employee creativity. Hence, we hypothesize that:

Hypothesis 1: Employees' perceptions of servant leadership will mediate the relationship between the complementarity of innovation strategy execution and innovation-led HR policy and employee creativity.

\section{Mediating Role of Employee Creativity}

In order to further explore the importance of servant leadership to employee creativity and firm innovation, we position servant leadership as a predictor of firm innovation mediated by employee creativity. To do so, we further extend the characteristics of servant leadership theory that are particularly relevant to developing emoployees' creative behaviors. We therefore argue that 'leaders earn trust when they place the legitimate needs of their followers above self-interests' (Wong \& Davey, 2007, p. 3). On the basis of this assumption, we suggest that by putting employees at the center of concentric circles (Wong \& Davey, 2007), employees are likely to believe that leaders 'will provide necessary resources, support and backing for unpopular ideas' (Madjar \& Ortiz-Walters, 2009, p. 130). In other words, when employees really trust their leaders, they believe that their leaders trust and support them to take risks, and seek new or novel ways of doing their jobs in order to increase their labor productivity, which in turn contribute to their organizational performance. Another important characteristic of servant leadership is that leaders seek to achieve organizational goals by developing and unleashing the creative potential of human resources (Wong \& Davey, 2007, p. 3). To do so, leaders not only develop a high-quality human capital pool with the necessary knowledge, skills and motivation, but they also give them the opportunity and create the most 
supportive work environment conducive for their creative capabilities to foster their job productivity and performance. As such, employees are more likely to innovate in their work because their employers expect them to do so in order to achieve their set goals.

Taken together, we argue that when the relevant components of servant leadership are coherently interacted and complemented, employees will likely have both necessary and sufficient conditions to innovate and perform best. This is supported by empirical evidence that servant leadership influences individual creativity and team innovation channelized by employee relational identification and collective prototypically with the leader (Yoshida et al., 2014). Also of note is that creativity happens primarily at the early phases of innovation processes with innovation implementation later (West, 2002). In this regard, individual creativity is a starting point for innovation (Bidault \& Castello, 2009; Zhou \& George, 2001). Coupled with this logic, employee creativity is likely to contribute to firm innovation. As such, organizations need to effectively invest in servant leaders so that they are able to represent the organization as developing a safe and supportive work environment for workers to activate their potential and abilities to perform and contribute (see also Zhang et al., 2012). In line with this, we position employee creativity as an important mechasim that mediates the servant leadershipfirm innovation linkage. We thus posit that:

Hypothesis 2: Employee creativity mediates the relationship between employees' perceptions of servant leadership and firm innovation.

\section{Mediating Role of Firm Innovation}

Earlier field work has establsihed the linkage between innovation and organizational performance (Hult, Hurley, \& Knight, 2004; Oke et al., 2012; Yeh-Yun Lin \& Yi-Ching Chen, 2007). Oke et al. (2012), for example, found that the relationship between innovationled strategy and innovation-led HR policy interactions and firms' revenue is mediated by 
innovation performance. Additionally, Hult et al. (2004) demonstrated that innovativeness is positively associated with business performance. Drawing upon these empirical demonstrations and insights from componential theory of creativity, we argue that innovation is contingent on (a) domain-relevant skills of employees, (b) motivation to innovate, and (c) the work environment (Amabile, 2012).

With respect to the first component - the domain relevant skills, we can see that there is a close link between HR practices and employee skills. HR practices that effectively invest in people are likely to develop the skills, competences, knowledge and motivation of employees (e.g., rigorous selection, extensive training). As regards the second component task motivation, employees are required to be intrinsically motivated in order to activate their abilities and innovate in their work. Organizations therefore need to focus on innovative HR practices such as job design, teamwork, information sharing in order to make work tasks more interesting and meaningful, thereby enabling and motivating employees to think and perform creatively. The final component is that of the work environment. Although the first two components are considered as prerequisites to employee creativity, they are known to be insufficient for employees to best perform and innovate without the supportive work environment. Therefore, along with the skills and motivation of employees, firms are required to create a safe and supportive work environment for employees to have the opportunity to turn their skills, knowledge and motivation into their higher work productivity and creative performance. These components then shape the work environment that influences both individual employees and firms (Amabile, 2012). We therefore extend the componential theory of creativity to describe the process of firm innovation, based on the idea that creativity is the generation of new and novel ideas and usually occurs at the individual level, while innovation is the implementation of such ideas, and normally occurs at the organizational 
level (Amabile, 2012; 1996; Zhou \& Hoever, 2014; Oldham \& Cummings, 1996). Based on the aforementioned theoretical developments, we aim to gain insights into this issue by adopting constructs of employee creativity, innovation performance and market performance to develop our next hypothesis. Following this, we hypothesize innovation performance as a mechanism that mediates the relationship between employee creativity and market performance.

Hypothesis 3: Firm innovation mediates the relationship between employee creativity and firm market performance.

\section{METHODS}

Prior proceeding to a main study, we conducted a pilot interview with managers and/or HR managers of Vietnamese service firms. The primary purpose of the pilot was to detect whether management initiatives were extensively practiced within firms, and to what extent they were universally applicable and were Vietnam specific. Using inputs from the interviews, we selectively adopted management practices that were most commonly implemented by Vietnamese firms. By doing so, we could adapt management practices that have been empirically examined and validated by recent scholars (Oke et al., 2012). Once the whole survey questions had been translated into Vietnamese and then back-translated into English, we consulted the final Vietnamese version with Vietnamese academic researchers and service firm managers to assess the face and content validity of the scales in the Vietnamese context (Patel et al., 2013). Using feedback from these participants, we made necessary changes in the wording of the survey items before running the survey.

The current study decided to choose the Vietnamese service sector as the empirical context to test the hypothesized multilevel structural models. The data were collected via a questionnaire survey of firms in the large cities of Ha Noi, Thanh Hoa and Da Nang between 
April and June 2014. Using the list of firms provided by the Vietnam Chamber of Commerce and Industry (VCCI), 300 firms were contacted and 80 agreed to participate in the survey. Each survey package contained three separate questionnaires each directed to managers, supervisors and employees. A cover letter attached to each questionnaire explained the purpose of the survey and assured the respondents that their participation was voluntary and they had the right to withdraw at any time without repercussions. To avoid common method bias, we collected the data from different sources. For each firm, the manager questionnaire requested the managers and deputy managers to rate management initiative practices, firm innovation and market performance. The supervisor questionnaire was administrated to the immediate supervisors who provided data on employee creativity. The employee questionnaire asked the frontline employees to rate their perceptions of servant leadership. To ensure that supervisor and employee questionnaires would be matched, each employee questionnaire was labeled with running numbers from 0001-1000. Also, the supervisor questionnaire had the same running numbers, and the employee matching codes was kept with the researchers. Separate envelops with prepaid postage were provided for the HR managers to return completed surveys to the given address. Of the 80 survey packages distributed, 61 were returned. More specifically, we received questionnaires from 117 managers and/or HR managers, 164 supervisors and 576 employees from 61 firms, representing a response rate of 87 percent. After deleting uncompleted questionnaires and records with unmatched questionnaires between the employees and their supervisors, we obtained a final sample of 56 firms (109 managers, 153 supervisors and corresponding 526 employees). On average, an immediate supervisor rated at least 3 subordinates (ranging from 3 to maximum 5).

\section{Measures}


As Vietnamese is the official language of commerce and administration in Vietnam, hence the questionnaires were administrated in Vietnamese. The questionnaires were originally designed in English, and then translated into Vietnamese to ensure its consistency and reliability. In order to achieve this goal, we followed the procedure proposed by Brislin (1970). Specifically, this process was undertaken with the assistance of Vietnamese HR specialists who have a good command of English. The English version was translated into Vietnamese by a HR specialist and then back translated into English by another specialist. The back-translated version was compared with the original to ensure accuracy (Akhtar et al., 2008), and consistency of meaning (Chang \& Chen, 2011). Following this, we compared the original version and the back-translated version, and did not view cross-cultural construct validity as a problem in our analysis (Kearney et al., 2009).

Management initiatives. This index was measured combining innovation-led strategy with a four item scale developed by Oke et al. (2012); and innovation-led HR policy with a five-item scale developed by Oke et al. (2012). Items were rated on a five-point scale, from 1 $=$ 'Totally Disagree' to $5=$ 'Totally Agree'. Its sample items are 'Management spends sufficient time and money supporting innovation,' 'Innovation forms part of our training and development programs.' Together, the scale was based on two distinct dimensions for management initiatives: innovation-led strategy and innovation-led HR policy.

In order to further confirm its validity and reliability, we conducted a confirmatory factor analysis (CFA) to test the factor structure of the 9 management initiatives practices. We confirmatory-analyzed the fit of management initiatives index via the construction of a second-order factor from two dimensions that compose it. The result indicated a good data fit with indices of fit $\left(\chi^{2}=205.25 ; \mathrm{df}=76 ; \mathrm{p}<.05 ; \mathrm{CFI}=.10 ; \mathrm{TLI}=.10 ; \mathrm{RMSEA}=.05 ; \mathrm{SRMR}\right.$ $=.03)$. The Cronbach's alpha for this scale is .80 . 
Servant leadership. This was measured using a 14-item scale adopted from Ehrhart (2004). Its items were rated on a five-point scale, from $1=$ 'To a Very Small Extent' to $5=$ 'To a Very Great Extent. The sample items are 'My firm manager spends the time to form quality relationships with his/her employees,' 'My firm manager does what she or he promises to do.' The Cronbach's alpha for this scale is .82 .

Employee creativity. The employee creativity measure was calculated using a 13-item scale adopted by Zhang and Bartol (2010). Its items were rated on a five-point scale, from $1=$ 'Not at all Characteristic' to $5=$ 'Very Characteristic'. Its sample items are 'Often has new and innovative ideas,' 'Suggests new ways to increase quality.' Its Cronbach's alpha is .80 .

Firm-level innovation. I used a nine-item scale by García-Morales, JiménezBarrionuevo, and Gutiérrez-Gutiérrez (2012), but originally developed by Antoncic and Hisrich (2001). This scale is undimesional (García-Morales et al., 2012). Firm managers were asked to rate the growth of their firm innovation in the past three years. The items were rated on a seven-point scale, from $1=$ 'Totally Disagree' to 7 = 'Totally Agree'. Its sample items are 'Firm's emphasis on developing new products or services,' 'Firm's spending on new product or service development activities.' A number of researchers have examined firm innovation utilizing this reliable valid scale that enables its measurement (Antoncic \& Hisrich, 2001; García-Morales et al., 2012). Its Cronbach's score alpha is .91.

Market performance was measured using a four-item scale adopted by Delaney and Huselid (1996) to measure firm-level market performance. The focus of these items is on marketing, sales, growth and market share. Firm managers provided data on the performance of their firm relative to that of their competitors in the past 12 months (see also Aryee et al., 2012). Items were rated on a four-point scale, from 'Worse' to 'Much Better,' where $1=$ and $4=$. Although it would better to have an objective measure tested, it is precedent in the 
existing literature for employing subjective measures of firm performance outcomes (Aryee et al., 2012; Delaney \& Huselid, 1996; Takeuchi et al., 2007; Wall, Michie et al., 2004 ). In support of this view, scholars have provided evidence for the convergent, discriminant, and construct validity of subjective and objective measures of firm performance (e.g., Wall et al., 2004). As such, García-Morales et al. (2012, p. 1044) conclude that there is " a high correlation and concurrent validity between objective and subjective data on performance, implying that both are valid when calculating a firm's performance''. Following this logic, we argue that subjective and objective measures of company performance can be treated as equivalent (Wall et al., 2004). Therefore, we used this subjective measure to examine the market performance of Vietnamese service firms. Its Cronbach's alpha score is .68.

Controls. Given the multilevel nature of the study, we control for both individual-level and firm-level control variables. At the individual level, we control for (1) employee age, and (2) gender, measured as a dummy variable $(1=$ male, $0=$ female $)$. By including these factors, we control for the potential impacts of employee demographic differences, such as gender and tenure (Jensen, Patel, \& Messersmith, 2013), which may influence the way an employee feels about their perceptions of servant leadership. At the firm level, we control for firm size, age and ownership. Firm age is calculated based on its founding date as recognized in the survey (McClean \& Collins, 2011). Specifically, the measure of firm age is taken from the question 'How long has your firm been in operation?' (Guthrie, Flood, Liu, MacCurtain, \& Armstrong, 2011). Firm size is viewed as a control as it can be related to the utilization of HPWSs (Liu, Guthrie, Flood, \& MacCurtain, 2009), the effect of the HPWS on the firm (Klaas, Semadeni, Klimchak, \& Ward 2012) and the personnel function affecting the use of certain HR practices (McClean \& Collins, 2011). It is also important to note that size is measured as the logarithm of the number of full-time workers (Sun et al., 2007; Liao et al., 2009) at the time of the 
survey (Klaas et al., 2012). A final control variable is ownership, which prior research has found to be associated with performance and HR policies and practices (Sun et al., 2007). Firm ownership has two categories: public (state- and collectively owned) and not public (share-holding, foreign-invested, and privately owned), measured as a dummy variable $(1=$ “"public,', $0=$ “"not public'’).

\section{Statistical Analysis}

Given the hierarchical nature of the data, with employees nested within firms, and the complex research model, we adopted Mplus Version 7.13 (Muthén \& Muthén, 1998-2014) to measure the multilevel structural equation models (MSEM). We adopted MSEM for a number of reasons. First, using MSEM can help overcome several limitations of multilevel modeling (Preacher, 2011; Preacher, Zhang, \& Zyphur, 2011; Preacher, Zyphur, \& Zhang, 2010). For example, MSEM is more appropriate for testing multilevel mediations than hierarchical linear modelling method (Preacher et al., 2010; see also Sun et al., 2012). Second, MSEM is a powerful tool that does not require outcomes to be measured at Level 1, nor does it require a two-phase analysis, as opposed to three procedures (two-step, aggregation, and disaggregation) (Preacher et al., 2010). In this regard, the whole measurement is tested together to reach the effects of path $a$, path $b$ and the indirect effect. Third, MSEM provides fit indices that allow researchers to measure the absolute and relative fit of models while it is not easy to do so in the MLM framework (Preacher et al., 2010). In doing so, it offers the opportunity to assess fit at the overall, between-group (level 2), and within group (level 1) levels (Ryu, 2011). Further, MSEM conjoins the best of both multilevel modeling and structural equation modeling, thereby allowing full-blown SEM models to be developed at each level of nesting for clustered data (Mehta \& Neale, 2005). Finally, the Mplus software 
can allow us to utilize a full information maximum likelihood estimator for all analyses (Jensen, Patel, \& Messersmith, 2013).

Following this prescription, we first tested the correlations among the variables of the study (Beltrán-Martín, Roca-Puig, Escrig-Tena, \& Bou-Llusar, 2008). We then assessed whether the trends of mean scores and correlations of the study variables were valid and reliable for hypotheses testing. We finally tested the structural models corresponding to the proposed hypotheses: (1) a 2-1-1 mediation model; (2) a 1-1-2 mediation model; and (3) a 12-2 mediation model.

\section{RESULTS}

Table 1 shows the descriptive means, standard deviations and corrections of the study variables.

Insert Table 1 about here

\section{Validity and Reliability of the Variables}

Table 1 presents descriptive statistics on the management initiatives index and outcome-related constructs, and the zero-order correlations between them. We can see that management initiatives, firm innovation and market performance obtain relatively high mean scores of 4.13, 5.19 and 3.42, respectively, while servant leadership and creativity demonstrate lower scores of 3.78 and 3.64, respectively. Also of note is that correlations between management initiatives and servant leadership, creativity, innovation and market performance range from .05 to $.17^{* *}$, suggesting that there are positive correlations among the variables. 
Table 1 also demonstrates that the mean score for creativity $(M=3.64)$ is lower than the mean score for innovation $(\mathrm{M}=5.19)$. Correlations of management initiatives with servant leadership and creativity $\left(r=.11^{* *}\right.$ and $.10^{* *}$, respectively; $\left.\mathrm{p}<.01\right)$ demonstrate strong and positive relationships between these variables. Likewise, innovation is strongly and positively correlated with market performance $\left(r=.12^{* *} ; \mathrm{p}<.01\right)$. Most importantly, management initiatives have a strong and significant correlation with market performance $(\mathrm{r}=$ $\left..07^{* *} ; \mathrm{p}<.01\right)$. The result reflects that management initiatives are likely to be a strong potential predictor of market performance. Taken together, the descriptive information suggests that (1) the study variables are distinct from one another, and (2) of the statistical relationships between the management initiatives index and the outcome-related constructs, the majority of constructs are positively correlated with one another. Therefore, we conclude that they are valid and reliable for our analyses.

\section{Hypotheses Testing}

The results of the estimation are presented in Table 2. Consistent with the work by Jensen et al. (2013), the residual covariance matrix is used, which is derived after removing the effects of control variables. Hypothesis 1 predicted that the relationship between the complementarity of innovation strategy execution and innovation-led HR policy and employee creativity is mediated by servant leadership. We employed a 2-1-1 model to test this hypothesis, using the Mplus syntax proposed by Preacher et al. (2011); Preacher et al. (2010), controlling for firm size, age and ownership as Level 2 effects and employee age and gender as Level 1 effects in our analyses. The results demonstrated the partial mediation of innovation strategy execution and innovation-led HR policy combination on employee creativity was significant $(\beta=.16 ; \mathrm{p} \geq .05 ; 95 \%$ of confidence interval $=.06$ to .37$)$, providing support for hypothesis 1 . Hypothesis 2 stated that employee creativity would 
mediate the relationship between servant leadership and firm innovation. We conducted a 1-12 model to test this hypothesis, following the same method and procedure as Hypothesis 1 and controlling for firm size, age and ownership as Level 2 effects and employee age and gender as Level 1 effects in our analyses. The results showed the partial mediation of servant leadership on firm innovation was significant $(\beta=.09 ; \mathrm{p}<.05 ; 95 \%$ of confidence interval $=$ .07 to .34 ), providing support for hypothesis 2 . Finally, hypothesis 3 suggested the mediating influence of firm innovation on the relationship between employee creativity and market performance. We adopted a 1-2-2 model to test this hypothesis, using the Mplus syntax proposed by Preacher et al. (2011); Preacher et al. (2010), controlling for firm size, age and ownership as Level 2 effects and employee age and gender as Level 1 effects in our analyses. The Level 1 indirect effect of employee creativity on firm market performance as partially mediated by branch-level innovation was significant $(\beta=.05 ; \mathrm{p}<.05 ; 95 \%$ of confidence interval $=.00$ to .05$)$, thus supporting hypothesis 3 .

Insert Table 2 about here

\section{DISCUSSION}

The primary purpose of this study is to explore the effects of management initiative practices and firm performance. In developing the hypotheses, we relate constructs of innovation-led strategy, innovation-led HR policy, servant leadership, employee creativity and innovation to the theoretical perspectives of servant leadership and creativity to gain insights into the linkages between management initiatives and innovation performance via indirect mechanisms. In doing so, this study is among the first to examine such relationships via cross-level path analyses. In this area, scholars have investigated the relationships between 
management initiatives and firm innovation at the firm level of analysis (e.g., Oke et al., 2012). However, it is noteworthy that firms themselves do not 'perform'; it is employees of the firms that perform in ways that enable them to accomplish desirable performance output (Liao et al., 2009). Following this logic, employee performance becomes a critical performance criterion for management research to measure the efficacy of work systems (Liao et al., 2009). By analysing the aforementioned relationships at both individual and firm levels, our findings reflect that management initiatives can indirectly relate to firm performance through the underlying mechanisms of mediators. This study therefore sheds light on the relevant literature and offers a number of both theoretical and practical implications.

\section{Theoretical Implications}

First, our findings suggest that the mutual complementarity of innovation-led strategy and innovation-led HR policy as management initiatives can be a valuable channel to contribute to employee perceptions of servant leadership. We note that because the relationship between HR practices and firm performance has been criticized for its lack of theory (Beugelsdijk, 2008). In response to this, we tested the link between management initiatives and employee creativity through the mediating role of servant leadership by combining insights from the HR, leadership and creativity literatures and servant leadership perspective. It is for this reason that HR practices are argued to positively relate to individual outcomes such as trust, empowerment, and creativity (see, for example, Aryee et al., 2012; Beugelsdijk, 2008; Jiang et al., 2012; Liao et al., 2009; Zacharatos, Barling, \& Iverson, 2005). Therefore, "a full use of HRM is good for organizations" (Paauwe, Guest, \& Wright, 2013, p. 204). Servant leadership is accordingly argued to be part of the optimal use of HRM practices because the key idea of servant leadership theory is leaders' responsibility to build a 
supportive work environment that boosts innovation and facilitates intrinsic motivation, and to attempt to reach firm goals by cultivating and mobilizing the creative potential of subordinates (e.g., Greenleaf, 1977; Spears, 1994; Spears \& Lawrence, 2004). As such, we conclude that servant leadership theory is particularly relevant to explain the management initiatives-individual creativity relationship mediated by employee perceptions of servant leadership. Our results confirm this conceptual lens with empirical evidence. This is an advancement in terms of theoretical development and applicability.

We also find that employee creativity is an important outcome at the individual level that significantly contributes to firm innovation. This finding confirms the view that creativity is an initial and important phase of the whole innovation process (i.e., Zhou \& Hoever, 2014; Oldham \& Cummings, 1996; West, 2002). Therefore, we could argue that creativity is a very important prerequisite that leads to organizational innovation. For innovation to occur, organizations need to focus on fostering employee creativity. Once employees can perform their work creatively and effectively, they are likely to make significant contributions to organizational innovation and effectiveness. Our results provide evidence that employee creativity partially mediates the relationship between servant leadership and firm innovation, and thus support this argument.

Additionally, our findings reveal that organizations aiming to achieve success need to commence with their organizational innovation, especially in today's constantly changing market environment. However, it is noteworthy that innovation is just a necessary condition but not enough to ensure success. This is because the success of an organization depends on different factors such as people factors, competition, opportunities, and other contingencies. As argued earlier, employee creativity is an important outcome at the individual level that significantly contributes to firm innovation. This suggests that there is a close relationship 
among employee creativity, firm innovation and firm overall performance (see also Beugelsdijk, 2008; Jiang et el., 2012). We therefore hypothesized that firm innovation is a critical mechanism linking the relationship between innovation and market performance. The results provide empirical evidence for this relationship and thus our underlying assumption is supported. Our contribution therefore further expands the componential theory of creativity in order to describe the process of firm innovation, based on a conceptualization of innovation as the successful implementation of creative ideas within a firm (Amabile, 2012).

Central to these results is that of highlighting the importance of indirect effects on the relationship between management initiatives and organizational performance. Scholars suggest that HR activities focus on the strongest immediate influence on employee (Zhang \& Morris, 2014). This means that researchers are aware that individual performance is becoming increasingly important when investigating the mechanisms through which management initiatives relate to organizational outcomes. This is because employee outcomes are salient contributors of firm performance, meaning that the better employee outcomes organizations can obtain, the more gain organizations can achieve (Zhang \& Morris, 2014). Our results provide empirical evidence for this association via the mediating role of employee creativity. By doing so, this study provides more insights into the relationship between management initiatives and organizational performance via the individual outcomes - servant leadership and employee creativity.

Finally, this study deviates from the existing analytical approach by adopting multilevel structural equation models. Our literature review indicates that the majority of prior research has employed multilevel modeling to deal with the hierarchical nature of the data and conduct cross-level path analyses (e.g., Aryee et al., 2012; Takeuchi et al., 2007). Despite the popularity, this traditional analytical technique has been criticized for such issues as bias, 
confidence interval coverage, complex analytical procedures, clustered data (e.g., Preacher, 2011; Mehta \& Neale, 2005). In view of the above, this study adopts structural equation modeling with Mplus in order to overcome several limitations of such traditional techniques (Preacher, 2011; Preacher et al., 2011; Preacher et al., 2010). Our findings confirm that this analytical method is a powerful tool for testing clustered data and conducting path analyses.

\section{Practical Implications}

Our findings reveal that servant leaders can drive employee creativity. Therefore, service organizations should effectively invest in servant leaders so that they are able to represent the organization as developing a safe and supportive work environment for workers to activate their potential and abilities to perform and contribute (see also Zhang et al., 2012). Servant leaders therefore become role models for their subordinates to follow, and more importantly, they may translate their motivation and inspiration into employees so that individuals are likely to stay motivated and innovate in their work. We therefore argue that a supportive work environment plays a key role in enhancing employee performance generally, and their creativity in particular, and it is servant leaders that can foster and enhance such an environment as representatives of the firm. In this sense, organizations are expected to implement innovative management practices with the focus on developing highly motivated and qualified servant leaders who can lead their followers to perform in a way that best benefits the firm. Once individual employees feel that their leaders are really servant leaders, they are likely to trust more on organizations. When this psychological need is satisfied, employees will likely feel psychologically safe and creatively enhanced. By this logic, they are likely to be intrinsically motivated to experiment new ideas, and come up with new ways to deal with service-related problems. To sum up, innovation- and servant-led organizations should implement management initiatives to create a work environment of a servant-based 
firm rather than a boss-based one in order to enable, inspire and motivate employees to innovate and perform best for the development of the firm. If done so, employees are likely to contribute more to overall organizational innovation and success.

Our findings also demonstrate that innovation-led strategy and innovation-led HR policy complement each other well. The interaction of these two constructs is found to jointly influence employee's perceptions of servant leadership, which in turn contribute to employee creativity. Employee creativity subsequently contributes to firm innovation and firm market performance. This finding offers insightful implications for managerial decision making in firms (Beugelsdijk, 2008). As such, managers need to utilise HR practices to make use of the strengths of HR systems that are conducisve for employee creativity, and more remarkably, execute such practices in combination with innovation-led strategy (Beugelsdijk, 2008).

\section{Limitations and Future Directions}

This study has several limitations that should be acknowledged, but they also suggest some potential avenues for future research. First, this study uses a cross-sectional set of data collected at one time to explore the linkages between management initiatives execution and firm performance. It may impact inferences about causal linkages between variables (Harley et al., 2007). Future research should therefore adopt a longitudinal design to explore the linkages between management initiatives execution and firm performance. Second, the generalizability of this study may be limited because the sample was restricted to Vietnamese service organizations or organizations that are exposed to Vietnamese management styles so that the generalizability of the findings might be hindered (Chang \& Chen, 2011). Hence, it could be recommended that future research should be conducted in various research settings (Takeuchi et al., 2007), and multiple industry contexts (Arthur, 1994) to address this drawback. A third limitation of this study is that of adopting only subjective measures of 
employee creativity and firm innovation. This imperfection has been accepted from prior research (Aryee et al., 2012; McClean \& Collins, 2011; Takeuchi et al., 2007) as it would be hard to compare objective measures of performance (McClean \& Collins, 2011). In order to fill this limitation, future research should be able to employ both subjective and objective measures of employee creativity and innovation performance so as to replicate and extend the findings of this study. For example, researchers may examine more objective measurements of employee creativity such as a number of new ideas an employee proposes; a number of effective solutions an employee offers, etc.

\section{CONCLUSION}

The present study advances prior research by integrating both firm- and employeerelated outcomes in an overall model to examine their effects of management initiatives on servant leadership, employee creativity and firm innovation, which, in turn, effects on market performance. Drawing upon servant leadership theory and componential theory of creativity, we find various mediating roles (e.g., servant leadership, employee creativity and firm innovation). Management initiatives have an indirect effect on both employee creativity and firm innovation through the mediating roles of servant leadership and employee creativity, respectively. Employee creativity indirectly influences firm market performance via the mediating role of firm innovation. These results highlight the mechanisms through which management initiatives execution affects organizational performance, and offer insights into how to foster employee creativity from the various social-contextual factors through management initiative practices. 


\section{REFERENCES}

Adner, R. (2012). The wide lens: A new strategy for innovation. Penguin UK.

Akhtar, S., Ding, D. Z., \& Ge, G. L. (2008). Strategic HRM practices and their impact on company performance in Chinese enterprises. Human Resource Management, 47(1), $15-32$.

Amabile, T. (2012). Componential theory of creativity. Working Paper: Harvard Business School, 12-096

Amabile, T. M. (1998). How to kill creativity (Vol. 87). Boston, MA: Harvard Business School Publishing.

Amabile, T. M. (1996). Creativity in context. Boulder, CO: Westview Press.

Ang, S. H., Bartram, T., McNeil, N., Leggat, S. G., \& Stanton, P. 2013. The effects of highperformance work systems on hospital employees' work attitudes and intention to leave: a multi-level and occupational group analysis. The International Journal of Human Resource Management, 24(16), 3086-3114.

Antoncic, B., \& Hisrich, R. D. (2001). Intrapreneurship: Construct refinement and crosscultural validation. Journal of business venturing, 16(5), 495-527.

Arthur, J. B. (1994). Effects of human resource systems on manufacturing performance and turnover. Academy of Management Journal, 37(3), 670-687.

Aryee, S., Walumbwa, F. O., Seidu, E. Y., \& Otaye, L. E. (2012). Impact of highperformance work systems on individual-and branch-level performance: test of a multilevel model of intermediate linkages. Journal of Applied Psychology, 97(2), 287-300. 
Baer, M., \& Frese, M. (2003). Innovation is not enough: Climates for initiative and psychological safety, process innovations, and firm performance. Journal of Organizational Behavior, 24(1), 45-68.

Barney, J. B. (1991). Firm resources and sustained competitive advantage. Journal of Management, 17(1), 99-120.

Bartram, T., Stanton, P., \& Thomas, K. (2009). Good morning Vietnam: new challenges for HRM. Management Research News, 32(10), 891-904.

Beltrán-Martín, I., Roca-Puig, V., Escrig-Tena, A., \& Bou-Llusar, J. C. (2008). Human resource flexibility as a mediating variable between high performance work systems and performance. Journal of Management, 34(5), 1009-1044.

Beugelsdijk, S. (2008). Strategic human resource practices and product innovation. Organization Studies, 29(6), 821-847.

Bidault, F., \& Castello, A. (2009). Trust and creativity: understanding the role of trust in creativity-oriented joint developments. R\&D Management, 39(3), 259-270.

Brislin, R. W. (1970). Back-translation for cross-cultural research. Journal of Cross-Cultural Psychology, 1(3), 185-216.

Burns, T. E., \& Stalker, G. M. (1961). The management of innovation.

Cabrera, E. F., \& Cabrera, A. (2005). Fostering knowledge sharing through people management practices. The International Journal of Human Resource Management, 16(5), 720-735.

Chang, P. C., \& Chen, S. J. (2011). Crossing the level of employee's performance: HPWS, affective commitment, human capital, and employee job performance in professional service organizations. The International Journal of Human Resource Management, 22(04), 883-901. 
Colbert, B. A. (2004). The complex resource-based view: Implications for theory and practice in strategic human resource management. Academy of Management Review, 29(3), $341-358$.

Cooper, R. G., \& Edgett, S. J. (2010). Developing a product innovation and technology strategy for your business. Research-Technology Management, 53(3), 33-40.

Cooper, D., \& Thatcher, S. M. (2010). Identification in organizations: The role of selfconcept orientations and identification motives. Academy of Management Review, 35(4), 516-538.

Crespell, P., \& Hansen, E. (2008). Work climate, innovativeness, and firm performance in the US forest sector: in search of a conceptual framework. Canadian Journal of Forest Research, 38(7), 1703-1715.

Damanpour, F. (1991). Organizational innovation: A meta-analysis of effects of determinants and moderators. Academy of Management Journal, 34(3), 555-590.

Delaney, J. T., \& Huselid, M. A. (1996). The impact of human resource management practices on perceptions of organizational performance. Academy of Management Journal, 39(4), 949-969.

Ehrhart, M. G. (2004). Leadership and procedural justice climate as antecedents of unit-level organizational citizenship behavior. Personnel Psychology, 57(1), 61-94.

France, D. R., Leahy, M., \& Parsons, M. (2009). Attracting, developing and retaining talent. Research-Technology Management, 52(6), 33-44.

Fu, N., Flood, P. C., Bosak, J., Morris, T., \& O'Regan, P. (2015). How do high performance work systems influence organizational innovation in professional service firms?. Employee Relations, 37(2), 209-231. 
García-Morales, V. J., Jiménez-Barrionuevo, M. M., \& Gutiérrez-Gutiérrez, L. (2012). Transformational leadership influence on organizational performance through organizational learning and innovation. Journal of Business Research, 65(7), 10401050.

Golding, N. (2010). Strategic human resource management. Beardwell, J. and Claydon.

Gong, Y., Huang, J. C., \& Farh, J. L. (2009). Employee learning orientation, transformational leadership, and employee creativity: The mediating role of employee creative selfefficacy. Academy of Management Journal, 52(4), 765-778.

Greenleaf, R. K. (1977). Servant leadership: A journey into the nature of legitimate power and greatness. New York: Paulist Press.

Guest, D. E. (1997). Human resource management and performance: a review and research agenda. The International Journal of Human Resource Management, 8(3), 263-276.

Gumusluoglu, L., \& Ilsev, A. (2009). Transformational leadership, creativity, and organizational innovation. Journal of Business Research, 62(4), 461-473.

Guthrie, J. P., Flood, P. C., Liu, W., MacCurtain, S., \& Armstrong, C. (2011). Big hat, no cattle? The relationship between use of high-performance work systems and managerial perceptions of HR departments. The International Journal of Human Resource Management, 22(8), 1672-1685.

Harley, B., Allen, B. C., \& Sargent, L. D. (2007). High performance work systems and employee experience of work in the service sector: the case of aged care. British Journal of Industrial Relations, 45(3), 607-633.

Holcomb, T. R., \& Hitt, M. A. (2007). Toward a model of strategic outsourcing. Journal of Operations Management, 25(2), 464-481. 
Hult, G. T. M., Hurley, R. F., \& Knight, G. A. (2004). Innovativeness: Its antecedents and impact on business performance. Industrial Marketing Management, 33(5), 429-438.

Haq, U., I, Ali, A., Azeem, U., M, Hijazi, T., S, Qurashi, M., T, \& Quyyum, A. (2010). Mediation Role of Employee Engagement in Creative Work Process on the Relationship of Transformational Leadership and Employee Creativity. European Journal of Economics, Finance and Administrative Sciences, 25(1), 94-101.

Jensen, J. M., Patel, P. C., \& Messersmith, J. G. (2013). High-performance work systems and job control: consequences for anxiety, role overload, and turnover intentions. Journal of Management, 39(6), 1699-1724.

Jiang, J., Wang, S., \& Zhao, S. (2012). Does HRM facilitate employee creativity and organizational innovation? A study of Chinese firms. The International Journal of Human Resource Management, 23(19), 4025-4047.

Jiménez-Jiménez, D., \& Sanz-Valle, R. (2011). Innovation, organizational learning, and performance. Journal of Business Research, 64(4), 408-417.

Jung, D. I., Chow, C., \& Wu, A. (2003). The role of transformational leadership in enhancing organizational innovation: Hypotheses and some preliminary findings. Leadership Quarterly, 14(4), 525-544.

Katou, A. A., \& Budhwar, P. S. (2006). Human resource management systems and organizational performance: a test of a mediating model in the Greek manufacturing context. International Journal of Human Resource Management, 17(7), 1223-1253.

Kearney, E., Gebert, D., \& Voelpel, S. C. (2009). When and how diversity benefits teams: The importance of team members' need for cognition. Academy of Management Journal, 52(3), 581-598. 
Lado, A. A., \& Wilson, M. C. (1994). Human resource systems and sustained competitive advantage: A competency-based perspective. Academy of Management Review, 19(4), 699-727.

Lau, C. M., \& Ngo, H. Y. (2004). The HR system, organizational culture, and product innovation. International Business Review, 13(6), 685-703.

Laursen, K., \& Foss, N. J. (2003). New human resource management practices, complementarities and the impact on innovation performance. Cambridge Journal of Economics, 27(2), 243-263.

Liao, H., Toya, K., Lepak, D. P., \& Hong, Y. (2009). Do they see eye to eye? Management and employee perspectives of high-performance work systems and influence processes on service quality. Journal of Applied Psychology, 94(2), 371-391.

Liden, R. C., Wayne, S. J., Zhao, H., \& Henderson, D. (2008). Servant leadership: Development of a multidimensional measure and multi-level assessment. Leadership Quarterly, 19(2), 161-177.

Liu, W., Guthrie, J. P., Flood, P. C., \& MacCurtain, S. (2009). Unions and the adoption of high performance work systems: does employment security play a role?. ILR Review, 63(1), 109-127.

Klaas, B. S., Semadeni, M., Klimchak, M., \& Ward, A. K. 2012. High-performance work system implementation in small and medium enterprises: A knowledge-creation perspective. Human Resource Management, 51(4), 487-510.

Lorenz, E., \& Valeyre, A. (2005). Organisational Innovation, Human Resource Management and Labour Market Structure: A Comparison of the EU-15. The Journal of Industrial Relations, 47(4), 424-442. 
Madjar, N., \& Ortiz-Walters, R. (2009). Trust in supervisors and trust in customers: Their independent, relative, and joint effects on employee performance and creativity. Human Performance, 22(2), 128-142.

McClean, E., \& Collins, C. J. (2011). High-commitment HR practices, employee effort, and firm performance: Investigating the effects of HR practices across employee groups within professional services firms. Human Resource Management, 50(3), 341-363.

Mehta, P. D., \& Neale, M. C. (2005). People are variables too: Multilevel structural equations modeling. Psychological Methods, 10(3), 259-284.

Messersmith, J. G., \& Guthrie, J. P. (2010). High performance work systems in emergent organizations: Implications for firm performance. Human Resource Management, 49(2), 241-264.

Michaelis, B., Wagner, J. D., \& Schweizer, L. (2015). Knowledge as a key in the relationship between high-performance work systems and workforce productivity. Journal of Business Research, 68(5), 1035-1044.

Murphy, T. E. (2002). Market forces and the Middle East's new interest in HRM. Business Horizons, 45(5), 63-71.

Neubert, M. J., Kacmar, K. M., Carlson, D. S., Chonko, L. B., \& Roberts, J. A. (2008). Regulatory focus as a mediator of the influence of initiating structure and servant leadership on employee behavior. Journal of Applied Psychology, 93(6), 1220.

Nohe, C., Michaelis, B., Menges, J. I., Zhang, Z., \& Sonntag, K. (2013). Charisma and organizational change: A multilevel study of perceived charisma, commitment to change, and team performance. The Leadership Quarterly, 24(2), 378-389. 
Oke, A., Walumbwa, F. O., \& Myers, A. (2012). Innovation Strategy, Human Resource Policy, and Firms' Revenue Growth: The Roles of Environmental Uncertainty and Innovation Performance. Decision Sciences, 43(2), 273-302.

Oldham, G. R., \& Cummings, A. (1996). Employee creativity: Personal and contextual factors at work. Academy of Management Journal, 39(3), 607-634.

Paauwe, J., Guest, D., \& Wright, P. (2013). HRM \& performance: Achievement \& challenges. New York: Wiley.

Patel, P. C., Messersmith, J. G., \& Lepak, D. P. (2013). Walking the tightrope: An assessment of the relationship between high-performance work systems and organizational ambidexterity. Academy of Management Journal, 56(5), 1420-1442.

Prajogo, D. I., \& Ahmed, P. K. (2006). Relationships between innovation stimulus, innovation capacity, and innovation performance. R\&D Management, 36(5), 499-515.

Preacher, K. J. (2011). Multilevel SEM strategies for evaluating mediation in three-level data. Multivariate Behavioral Research, 46(4), 691-731.

Preacher, K. J., Zhang, Z., \& Zyphur, M. J. (2011). Alternative methods for assessing mediation in multilevel data: The advantages of multilevel SEM. Structural Equation Modeling, 18(2), 161-182.

Preacher, K. J., Zyphur, M. J., \& Zhang, Z. (2010). A general multilevel SEM framework for assessing multilevel mediation. Psychological Methods, 15(3), 209-233.

Qiao, K., Khilji, S., \& Wang, X. (2009). High-performance work systems, organizational commitment, and the role of demographic features in the People's Republic of China. The International Journal of Human Resource Management, 20(11), 23112330. 
Ramdani, B., Mellahi, K., Guermat, C., \& Kechad, R. (2014). The efficacy of high performance work practices in the Middle East: Evidence from Algerian firms. The International Journal of Human Resource Management, 25(2), 252-275.

Reiter-Palmon, R., \& Illies, J. J. (2004). Leadership and creativity: Understanding leadership from a creative problem-solving perspective. The Leadership Quarterly, 15(1), 55-77.

Rosing, K., Frese, M., \& Bausch, A. (2011). Explaining the heterogeneity of the leadershipinnovation relationship: Ambidextrous leadership. Leadership Quarterly, 22(5), 956974.

Russell, R. F. (2001). The role of values in servant leadership. Leadership \& Organization Development Journal, 22(2), 76-84.

Ryu, E. (2011). Effects of skewness and kurtosis on normal-theory based maximum likelihood test statistic in multilevel structural equation modeling. Behavior Research Methods, 43(4), 1066-1074.

Searle, R. H., \& Ball, K. S. (2003). Supporting innovation through HR policy: evidence from the UK. Creativity and Innovation Management, 12(1), 50-62.

Seijts, G. H., \& Latham, G. P. (2005). Learning versus performance goals: When should each be used?. The Academy of Management Executive, 19(1), 124-131.

Selvarajan, T. T., Ramamoorthy, N., Flood, P. C., Guthrie, J. P., MacCurtain, S., \& Liu, W. (2007). The role of human capital philosophy in promoting firm innovativeness and performance: Test of a causal model. The International Journal of Human Resource Management, 18(8), 1456-1470.

Sendjaya, S., Sarros, J. C., \& Santora, J. C. (2008). Defining and measuring servant leadership behaviour in organizations. Journal of Management Studies, 45(2), 402424. 
Shekari, H., \& Nikooparvar, M. Z. (2012). Promoting leadership effectiveness in organizations: A case study on the involved factors of servant leadership. International Journal of Business Administration, 3(1), 54-65.

Shipton, H., West, M. A., Dawson, J., Birdi, K., \& Patterson, M. (2006). HRM as a predictor of innovation. Human Resource Management Journal, 16(1), 3-27.

Shin, D., \& Konrad, A. M. (2017). Causality between high-performance work systems and organizational performance. Journal of Management, 43(4), 973-997.

Shin, S. J., \& Zhou, J. (2003). Transformational leadership, conservation, and creativity: Evidence from Korea. Academy of Management Journal, 46(6), 703-714.

Spears, L. C. (1994). Servant leadership: Quest for caring leadership. Inner Quest, 2(5), 1-4.

Spears, L. C., \& Lawrence, M. (Eds.). (2004). Practicing servant-leadership: Succeeding through trust, bravery, and forgiveness. San Francisco, CA: Jossey-Bass.

Sun, L. Y., Aryee, S., \& Law, K. S. 2007. High-performance human resource practices, citizenship behaviour, and organisational performance: A relational perspective. Academy of Management Journal, 50(3), 558-577.

Sun, L. Y., Zhang, Z., Qi, J., \& Chen, Z. X. 2012. Empowerment and creativity: A cross-level investigation. The Leadership Quarterly, 23(1), 55-65.

Takeuchi, R., Lepak, D. P., Wang, H., \& Takeuchi, K. (2007). An empirical examination of the mechanisms mediating between high-performance work systems and the performance of Japanese organizations. Journal of Applied Psychology, 92(4), 1069.

Tierney, P., Farmer, S. M., \& Graen, G. B. (1999). An examination of leadership and employee creativity: The relevance of traits and relationships. Personnel Psychology, 52(3), 591-620. 
Tushman, M. L., Anderson, P. C., \& O’Reilly, C. (1997). Technology cycles, innovation streams, and ambidextrous organizations: organization renewal through innovation streams and strategic change. Managing Strategic Innovation and Change, 34(3), 323.

Van Dierendonck, D. (2011). Servant leadership: A review and synthesis. Journal of Management, 37(4), 1228-1261.

Vo, A. N. (2009). The transformation of human resource management and industrial relations in Vietnam. Chandos Publishing.

Vo, A., \& Hannif, Z. N. (2013). The reception of Anglo leadership styles in a transforming society: the case of American companies in Vietnam. The International Journal of Human Resource Management, 24(18), 3534-3551.

Wang, A. C., \& Cheng, B. S. (2010). When does benevolent leadership lead to creativity? The moderating role of creative role identity and job autonomy. Journal of Organizational Behavior, 31(1), 106-121.

Wang, P., \& Rode, J. C. (2010). Transformational leadership and follower creativity: The moderating effects of identification with leader and organizational climate. Human Relations, 63(8), 1105-1128.

Walumbwa, F. O., Hartnell, C. A., \& Oke, A. (2010). Servant leadership, procedural justice climate, service climate, employee attitudes, and organizational citizenship behavior: a cross-level investigation. Journal of Applied Psychology, 95(3), 517.

Wall, T. D., Michie, J., Patterson, M., Wood, S. J., Sheehan, M., Clegg, C. W., \& West, M. (2004). On the validity of subjective measures of company performance. Personnel Psychology, 57(1), 95-118. 
West, M. A. (2002). Sparkling fountains or stagnant ponds: An integrative model of creativity and innovation implementation in work groups. Applied Psychology, 51(3), 355-387.

Wong, P. T., Davey, D., \& Church, F. B. (2007). Best practices in servant leadership. Servant Leadership Research Roundtable, School of Global Leadership and Entrepreneurship, Regent University.

Yeh-Yun Lin, C., \& Yi-Ching Chen, M. (2007). Does innovation lead to performance? An empirical study of SMEs in Taiwan. Management Research News, 30(2), 115-132.

Yoshida, D. T., Sendjaya, S., Hirst, G., \& Cooper, B. (2014). Does servant leadership foster creativity and innovation? A multi-level mediation study of identification and prototypicality. Journal of Business Research, 67(7), 1395-1404.

Youndt, M. A., Snell, S. A., Dean, J. W., \& Lepak, D. P. (1996). Human resource management, manufacturing strategy, and firm performance. Academy of Management Journal, 39(4), 836-866.

Zacharatos, A., Barling, J., \& Iverson, R. D. (2005). High-performance work systems and occupational safety. Journal of Applied Psychology, 90(1), 77-93.

Zhang, B., \& Morris, J. L. (2014). High-performance work systems and organizational performance: testing the mediation role of employee outcomes using evidence from PR China. The International Journal of Human Resource Management, 25(1), 68-90.

Zhang, M., Zhu, C. J., Dowling, P. J., \& Bartram, T. 2013. Exploring the effects of highperformance work systems (HPWS) on the work-related well-being of Chinese hospital employees. The International Journal of Human Resource Management, 24(16), 3196-3212. 
Zhang, H., Kwong Kwan, H., Everett, A. M., \& Jian, Z. (2012). Servant leadership, organizational identification, and work-to-family enrichment: The moderating role of work climate for sharing family concerns. Human Resource Management, 51(5), 747 767.

Zhang, X., \& Bartol, K. M. (2010). Linking empowering leadership and employee creativity: The influence of psychological empowerment, intrinsic motivation, and creative process engagement. Academy of Management Journal, 53(1), 107-128.

Zhou, J., \& George, J. M. (2001). When job dissatisfaction leads to creativity: Encouraging the expression of voice. Academy of Management Journal, 44(4), 682-696.

Zhou, J. \& Hoever, I.J. (2014). Research on Workplace Creativity: A Review and Redirection. Annual Review of Organizational Psychology and Organizational Behavior, 1(1), 333-359.

Zhu, Y., \& Verstraeten, M. (2013). Human resource management practices with Vietnamese characteristics: a study of managers' responses. Asia Pacific Journal of Human Resources, 51(2), 152-174. 


\section{APPENDIX A}

FIGURE 1 (click here to go back)

Hypothesized Model

Firm level

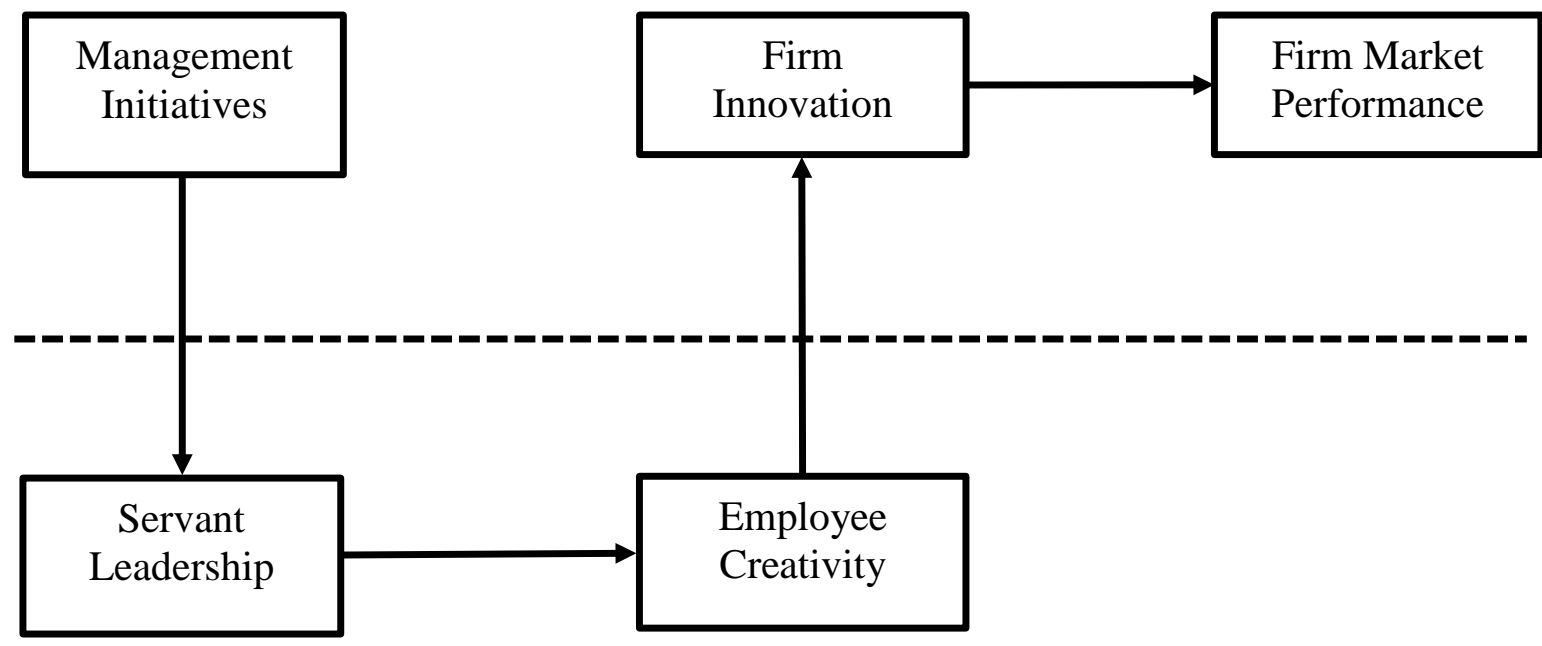

$\underline{\text { Individual level }}$ 


\section{APPENDIX B}

TABLE 1 (click here to go back)

Means, Standard Deviations and Correlations of Study Variables

\begin{tabular}{|c|c|c|c|c|c|c|c|c|c|c|c|c|}
\hline Variable & Mean & SD & 1 & 2 & 3 & 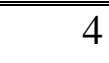 & 5 & 6 & 7 & 8 & 9 & 10 \\
\hline 1. Firm size & 1.47 & .89 & - & & & & & & & & & \\
\hline 2. Firm age & 2.97 & .87 & $.31^{* *}$ & - & & & & & & & & \\
\hline 3. Firm ownership & 1.58 & .49 & $-.39^{* *}$ & $-.19^{* *}$ & - & & & & & & & \\
\hline 4. Employee gender & 1.36 & .48 & -.01 & -.02 & .03 & - & & & & & & \\
\hline 5. Employee age & 1.61 & .64 & .06 & .08 & -.07 & .02 & - & & & & & \\
\hline 6. Management Initiatives & 4.13 & .47 & $.15^{* *}$ & $.15^{* *}$ & $.12^{* *}$ & -.07 & .04 & .80 & & & & \\
\hline 7. Servant Leadership & 3.78 & .60 & -.01 & -.05 & -.06 & .04 & -.04 & $.11^{* *}$ & .91 & & & \\
\hline 8. Employee Creativity & 3.64 & .63 & .05 & .07 & -.08 & .01 & .04 & $.10^{*}$ & .08 & .68 & & \\
\hline 9. Innovation & 5.19 & .83 & $.10^{*}$ & $.22^{* *}$ & -.04 & -.04 & $.09^{*}$ & .05 & -.04 & .05 & .88 & \\
\hline 10. Market performance & 3.42 & .32 & .17 & -.08 & .06 & $.23^{* *}$ & $.11^{*}$ & $.07^{* *}$ & .01 & $.17^{* *}$ & $.12^{* *}$ & .80 \\
\hline $\begin{array}{l}\text { Note: Coefficient alpha valt } \\
300 \text { employees, } 4=\text { over } 40 \\
=\text { public, } 0=\text { private } ; \text { Emplc } \\
\text { male, } 0=\text { female } \\
* \text { p }<.05 \\
* * p<.01\end{array}$ & $\begin{array}{l}\text { are pre } \\
\text { mploye } \\
\text { age c }\end{array}$ & $1=u$ & $\begin{array}{l}\text { ics alon } \\
\text { coded } \\
\text { er } 30 y\end{array}$ & $\begin{array}{l}\text { the dias } \\
=\text { under } \\
\text { rs, } 2=3\end{array}$ & $\begin{array}{l}\text { al; Brar } \\
\text { ears, } 2 \\
39 \text { years }\end{array}$ & $\begin{array}{l}\text { size c } \\
5-9 \text { yea } \\
=40-\end{array}$ & $\begin{array}{l}3=10 \\
\text { years, } 4\end{array}$ & $\begin{array}{l}0-199 \mathrm{em} \\
5 \text { years, } \\
=50-60 \mathrm{y}\end{array}$ & $\begin{array}{l}\text { oloyees, } \\
=\text { over } 1 \\
\text { ars; Em }\end{array}$ & $\begin{array}{l}=200-2 \\
\text { years; O } \\
\text { oyee gen }\end{array}$ & 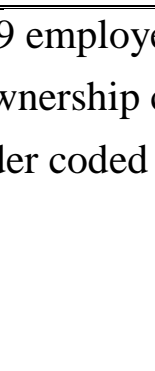 & $\begin{array}{l}\text { es, } 3= \\
\text { oded } 1 \\
=\end{array}$ \\
\hline
\end{tabular}


TABLE 2 (click here to go back)

Multilevel Path Analysis Results

\begin{tabular}{|c|c|c|c|c|}
\hline & $\begin{array}{c}\text { Standardised } \\
\text { betas }\end{array}$ & SE & $t$ Value & $\mathrm{p}$ \\
\hline LEAD $\rightarrow$ CRwithin & .26 & .04 & 3.46 & .00 \\
\hline MI $\rightarrow$ LEADbetween & .19 & .05 & 3.61 & .00 \\
\hline $\mathrm{LEAD} \rightarrow \mathrm{CR}$ & .86 & .40 & 2.15 & .03 \\
\hline $\mathrm{MI} \rightarrow \mathrm{CR}$ & .14 & .11 & 1.33 & .03 \\
\hline $\mathrm{MI} \rightarrow \mathrm{LEAD} \rightarrow \mathrm{CR}(\boldsymbol{H} \boldsymbol{1})$ & .16 & .09 & 1.82 & .06 \\
\hline LEAD $\rightarrow$ CRwithin & .04 & .07 & 0.53 & .02 \\
\hline $\mathrm{CR} \rightarrow$ INObetween & .12 & .32 & 1.37 & .01 \\
\hline LEAD $\rightarrow$ INObetween & .10 & .88 & 1.25 & .01 \\
\hline LEAD $\rightarrow$ CRbetween & .81 & .24 & 3.32 & .00 \\
\hline $\mathrm{LEAD} \rightarrow \mathrm{CR} \rightarrow \mathrm{INO}(\boldsymbol{H} 2)$ & .09 & .27 & 1.36 & .02 \\
\hline CRwithin variances & .58 & .11 & 5.14 & .00 \\
\hline $\mathrm{CR} \rightarrow \mathrm{INObetween}$ & .46 & .12 & 3.61 & .00 \\
\hline INO $\rightarrow$ PERbetween & .10 & .06 & 1.56 & .09 \\
\hline $\mathrm{CR} \rightarrow$ PERbetween & .89 & .25 & 1.84 & .04 \\
\hline $\mathrm{CR} \rightarrow \mathrm{INO} \rightarrow \operatorname{PER}(\boldsymbol{H} 3)$ & .05 & .02 & 2.16 & .03 \\
\hline
\end{tabular}

Covariance

$\begin{array}{lcccr}\text { MI, LEAD } & .16 & .04 & 4.46 & .00 \\ \text { LEAD, CR } & .04 & .01 & 3.24 & .00 \\ \text { MI, CR } & .12 & .03 & 3.46 & .00 \\ \text { CR, INO } & .10 & .03 & 3.99 & .00 \\ \text { INO, PER } & .28 & .05 & 5.78 & .00\end{array}$

Note: $\mathrm{MI}=$ Management Initiatives; LEAD = Servant Leadership; CR = Employee Creativity; INO = Firm Innovation; PER = Firm Market Performance. 